Page 232-246. ISBN: 978-602-6 988-75-1

Web Jurnal Online: jurnal.unmuhjember.ac.id

By: Sry Reski Mulka; Budiman; Andi Molang Chaerul; Nur Hasanah

The Impact of Coal Mining in Kota Samarinda

(Case Study of Conflict Between Government With Local Community in 2012-2014)

\title{
THE IMPACT OF COAL MINING IN KOTA SAMARINDA (CASE STUDY OF CONFLICT BETWEEN GOVERNMENT WITH LOCAL COMMUNITY IN 2012-2014)
}

\author{
${ }^{1}$ Sry Reski Mulka (Sryreskimulka27@gmail.com) \\ ${ }^{2}$ Budiman(buchos_unmul@yahoo.com) \\ ${ }^{3}$ Andi Molang Chaerul (amolchaerul@gmail.com) \\ ${ }^{4}$ Nur Hasanah (mksamarinda@gmail.com) \\ ${ }^{I}$ Mulawarman University \\ ${ }^{2}$ Mulawarman University \\ ${ }^{3}$ Andi Djemma University \\ ${ }^{4}$ Mulawarman University
}

\begin{abstract}
The research aims to describe and analyze chronologically and the cause of the conflict between the Government and the local community as the impact of coal mining in Kota Samarinda in 2012-2014. The research use qualitative method by means of case study, and validated by trianggulation. Library research, indepth interview, and documentation was used for collecting data. Data analyze conducted by described systematically regarded to the facts, properties and relationships amongs phenomena. The results of the research was the distrust of the local community to the government due to negligence for managing coal mining. Then, differences views of government to the locals for productive lands as the impact of mining. Furthermore, it lead to the some unmet local needs, such as good and healthy environ as well as public facilities are damaged.
\end{abstract}

Keywords: conflict, coal mining 
Proceeding ICOGISS 2019

Page 232-246. ISBN: 978-602-6 988-75-1

Web Jurnal Online: jurnal.unmuhjember.ac.id

By: Sry Reski Mulka; Budiman; Andi Molang Chaerul; Nur Hasanah

The Impact of Coal Mining in Kota Samarinda

(Case Study of Conflict Between Government With Local Community in 2012-2014)

\section{PRELIMINARY}

As one of the excellent commodities considered in Indonesia, the coal mining industry was like a coin, as a source of prosperity as well as a potential environmental destroyer. The first side, this sector contributes to economic movements in Indonesia. Not only as a source of state revenue by the taxes and royalties, but also able to created jobs for the community. The industry was a primary energy supplier, the level of dependence on coal was increasingly being followed by increasing oil prices because it plays a major role in being an efficient and economical replacement energy. However, coal mining activities also destroy the environment. It can totally change both climate and soil due to all soil layers above the deposit of mining material removed. Then the loss of vegetation indirectly thereby eliminating the function of the forest as a water regulator, erosion control, flooding, carbon sinks, oxygen suppliers and temperature regulators.

Regarding all, the effects of coal mining activities can cause social turmoil. This is due to the damage and pollution of the environment so that it is troubling for the people who live close to the mine area. Even with the existence of environmental damage and pollution often lead to various conflicts. Included vertical conflicts between communities and the government and companies due to differences in interests between communities living around the mining and the government and the companies.

Samarinda City is an interesting locus in observing conflicts between communities and the government due to the impact of coal mining. Not only because Samarinda City has a number of potential natural resources for extracting minerals. But also it is the only city that has coal mining activities in the middle of the city. With autonomy system, it has opened up space for the administration of the City to manage its own household, including the mining permits. By the authority, Kota Samarinda has the largest percentage of coal mining area in East Kalimantan Province. Based on data obtained from the Mining Advocacy Network (JATAM) that no less than 71 percent of the city of Samarinda has been granted mining permits by the local government. In 2001, the government issued one coal mining permit covering 87.52 hectares, in 2005 it increased to 38 permits covering an area of 20,323.1 hectares, and increased in 2009 to 76 licenses covering an area of 27,556.66 hectares. Then in 2005 to 2010, coal production in Samarinda City increased almost 13-fold. In 2005 its production was around 407,134.99 tons, the following year tripled to 1,580,553.99 tons, while in 2007 around 2,200,098.3 tons, doubled in 2008 to around 4,401,783 tons, and in 2009 became 5,132,914.74 tons.

With a sharp increase of the issuance of coal mining licenses, Samarinda City has faced very serious environmental problems. Prasodjo (2015) said that all coal mining in the city was carried out by means of open mining which in the operational stages of the activity caused disruption to environmental conditions. The conversion of forest land into a coal mine has resulted in the forests remaining 0.9 percent of the total area of the city which covers 71,800 hectares. According to the Mayor's Decree, No. 178 / HK-KS / 2005 where 30 percent of the city area must be a green open area as a water catchment unit. Damage to forests and water catchment areas is the main cause of the city often experienced flooding. 
Proceeding ICOGISS 2019

Page 232-246. ISBN: 978-602-6 988-75-1

Web Jurnal Online: jurnal.unmuhjember.ac.id

By: Sry Reski Mulka; Budiman; Andi Molang Chaerul; Nur Hasanah

The Impact of Coal Mining in Kota Samarinda

(Case Study of Conflict Between Government With Local Community in 2012-2014)

In af agriculture, the damage to land and ground causes destruction of rice fields. The results in diminishing productive paddy fields due to submerged mud and this condition is further aggravated by increasingly damaged water sources. This is proven by BPS data 2005 to 2010, it was recorded that the area decreased by an average of about 340 hectares per year. Furthermore, quoting from the July 21, 2014 edition of Kaltim Post, that the effects of coal mining resulted in polluted air pollution so that people living around are vulnerable to diseases of the respiratory system. With these various conditions increasingly complexes that 1.4 million hectares of open land where 839 thousand hectares have not been reclaimed resulting in the loss of the lives of eight children in 2011 to 2014 in coal mining holes that have not been reclaimed.

According to these facts, the condition of environmental damage in Samarinda City due to coal mining turned out to be increasingly post-regional autonomy. Because, with the decentralization system, it requires the active role of the city administration to maximizing the potential of coal resources. This is what makes exploitative development policies on coal resources at the era of regional autonomy unavoidable. Coal mining has political dimensions and implications, where actors such as the government and companies have the power and capital to determine patterns and directions for the use of natural resources. This is easily proven by the City Government issuing permits for coal management for companies without adhering to the principle of environmental balance. While the community is the weakest party and is a victim of the impacts. Even so far, the dredging of coal is far from the promise made by the City Administration, that mining will prosper the community through employment and infrastructure development. Based to these various problems, resulting in a reaction of the people, especially who are directly affected by mining, which raises a phenomenon that is the occurrence of conflict between the community and the Adminstration.

The initiative condition of the conflict began in 2012, in which the community protested and objected to the impact of the mine voiced by the community starting from blocking roads, carrying out various demonstrations on the streets, in offices, in the DPRD building, to the Samarinda Mayor's office. However, protests and objections to the impact of the mine voiced by various parties were not enough to get a satisfactory response from the local government. This made the potential for conflict to become increasingly complex, so that the community and several non-governmental organizations (NGOs) and student organizations formed a coalition namely the Samarinda Claim Movement (GSM). GSM consists of citizens (individuals), student organizations, academics, JATAM, POKJA 30, BEBSiC, BIOMA, NALADWIPA, KOMKEP, GUSDURIAN Kaltim, and LMND Samarinda.

Through Movement, on June 25, 2013 the community of Samarinda City used Citizen Lawsuit (CLS) to sue government institutions regarding state administrators' policies which resulted in problems with the impact of coal mining. There were 19 residents of Samarinda City consisting of farmers, academics, students, private sector, and Housewives (IRT) filing a lawsuit to the Samarinda District Court (PN), one of the government institutions that became the defendant was the Administration of Samarinda City. In the lawsuit, the community considers that the Administration of Samarinda City 
Page 232-246. ISBN: 978-602-6 988-75-1

Web Jurnal Online: jurnal.unmuhjember.ac.id

By: Sry Reski Mulka; Budiman; Andi Molang Chaerul; Nur Hasanah

The Impact of Coal Mining in Kota Samarinda

(Case Study of Conflict Between Government With Local Community in 2012-2014)

is negligent in carrying out its obligations to create a good and healthy environment so that climate change occurs in Samarinda City. Therefore, through the lawsuit, the community demands the government's responsibility to evaluate all coal mining licenses that have been issued, supervise business actors to realize reclamation and post-mining, improve environmental functions, and make strategic efforts in protecting the agricultural and fisheries areas of the community from pollution as a result of coal mining activities.

By the explanation, the conflict between them regarding the issue of exploitative economic political policies on coal resources, is evidence of the occurrence of vertical conflict even though it does not cause violence. Until now, the conflict is still very warmly discussed because for the first time in the history of law in Indonesia, the community has filed a lawsuit against a citizen law (CLS) that represents the public interest, especially in relation to the impact of coal mining. Thus this study seeks to examine in depth the dynamics of community conflict with the administration regarding cases of the impact of coal mining in Samarinda City based on the chronology of the conflict that occurred.

Framework

The research began from the perspective that not all levels of society welcome the presence of coal mining activities. Facts that exploitation of coal mining has the potential to cause conflict. Fisher (2001: 4) explains that conflict is a relationship between two or more parties, both individuals and groups who feel or have goals that are not in line. It can be observed that research that concerns the vertical conflict between communities and the government due to the impact of coal mining has not received much attention, therefore the research more specifically to describe and analyze the causes of conflict between the government and the community for coal mining impacts. The theory of conflict from Simon Fisher (2011) to describe the causes of conflict between government and society in the case of the impact of coal mining. Theoretically, the causes of conflict according to Fisher et al. Include: First, public relations theory. That the cause of conflict is that polarization (opposing groups) continues to occur, distrust and hostility between different groups in a society. Second, the principle negotiation theory. That conflict is caused by incongruent positions and differences in views about conflict between the parties involved. Third, the theory of human needs. That conflicts that arise in the community are caused by basic human needs that are not fulfilled or obstructed (Simon Fisher, 2001: 7-8).

\section{METHOD}

The study have a qualitative approach was used. It is considered relevant and in accordance with the research that will be conducted to obtain a real understanding of the conflict between the government and the community in the case of the impact of coal mining in Samarinda City. According to Creswell (2010: 4), qualitative research is methods for exploring and understanding meaning that by a number of individuals or groups of people are ascribed to social or humanitarian problems. Furthermore, the selection of qualitative techniques relates to a number of characteristics of qualitative 
Proceeding ICOGISS 2019

Page 232-246. ISBN: 978-602-6 988-75-1

Web Jurnal Online: jurnal.unmuhjember.ac.id

By: Sry Reski Mulka; Budiman; Andi Molang Chaerul; Nur Hasanah

The Impact of Coal Mining in Kota Samarinda

(Case Study of Conflict Between Government With Local Community in 2012-2014)

research (Creswell, 2009: 195). In connection with these characteristics, there are several steps taken by the author, which can be seen in the following table:

\begin{tabular}{|c|c|c|}
\hline No. & Qualitative research according to Creswell & Steps taken \\
\hline 1. & $\begin{array}{l}\text { Qualitative research takes place in natural } \\
\text { settings in the form of behaviors and events } \\
\text { (Creswell, 2009: 195) }\end{array}$ & $\begin{array}{l}\text { Natural settings of the study are } \\
\text { chronological determinations of conflict } \\
\text { then observed are causes of Government } \\
\text { and Community conflicts in the case of } \\
\text { coal mining impacts in Samarinda City. }\end{array}$ \\
\hline 2. & $\begin{array}{l}\text { Placement of theory in qualitative research } \\
\text { can be in various ways, namely the initial } \\
\text { theory of research, or the final theory of } \\
\text { research. Theories may appear at the } \\
\text { beginning and be modified or adjusted } \\
\text { based on the informant's view. This model } \\
\text { is not being tested, researchers propose a } \\
\text { modified model. The theory used at the } \\
\text { beginning serves as an explanation for } \\
\text { behavior and attitudes and may be complete } \\
\text { with variables, constructs and hypotheses. } \\
\text { Although researchers do not refer to them } \\
\text { as theories, they provide a broad } \\
\text { explanation. So that in qualitative research } \\
\text { researchers do not position the theory in a } \\
\text { central position when designing research } \\
\text { and interpreting data. Placement of theory } \\
\text { in qualitative research is used as a guideline } \\
\text { for verification and analysis when } \\
\text { spaciousness (Creswell, 2009: 65). }\end{array}$ & $\begin{array}{l}\text { The selection of the theory placement in } \\
\text { qualitative research is a theory placed at the } \\
\text { beginning of the study, where the } \\
\text { researcher refers to Simon Fisher's theory } \\
\text { used to explain the causes of conflict which } \\
\text { are used as references for data collection in } \\
\text { cites. At the end of the study, researchers } \\
\text { modified the theory according to the data } \\
\text { obtained in cites and after data analysis. } \\
\text { thus a modified model is available at the } \\
\text { end of the study }\end{array}$ \\
\hline 3. & $\begin{array}{l}\text { The researcher is an instrument in data } \\
\text { collection (Creswell, 2009: 195). }\end{array}$ & $\begin{array}{l}\text { The researcher is an instrument in } \\
\text { collecting data, so that researchers function } \\
\text { in selecting informants as data sources and } \\
\text { collecting data (observation, interviews, } \\
\text { looking for secondary data) where the next } \\
\text { step is data analysis and conclusions. }\end{array}$ \\
\hline 4. & $\begin{array}{l}\text { Data obtained from qualitative research is } \\
\text { descriptive, words or images (Creswell, } \\
\text { 2009: 195). }\end{array}$ & $\begin{array}{l}\text { The data obtained from qualitative research } \\
\text { is in the form of interviews with } \\
\text { informants, which are recorded and } \\
\text { processed into words (transcripts of } \\
\text { interviews). Events are recorded in the } \\
\text { form of images. In addition there are also }\end{array}$ \\
\hline
\end{tabular}


Proceeding ICOGISS 2019

Page 232-246. ISBN: 978-602-6 988-75-1

Web Jurnal Online: jurnal.unmuhjember.ac.id

By: Sry Reski Mulka; Budiman; Andi Molang Chaerul; Nur Hasanah

The Impact of Coal Mining in Kota Samarinda

(Case Study of Conflict Between Government With Local Community in 2012-2014)

\begin{tabular}{|l|l|l|}
\hline 5. & $\begin{array}{l}\text { Individuals develop subjective meanings } \\
\text { from their experiences. This meaning varies } \\
\text { and encourages researchers to look for } \\
\text { complex views (Creswell, 2009: 8). The } \\
\text { focus of qualitative research is the } \\
\text { perceptions and experiences of informants, } \\
\text { and the way they understand their lives } \\
\text { (Creswell, 2009: 195). }\end{array}$ & $\begin{array}{l}\text { The data obtained from the research is the } \\
\text { result of interviews from informants. Thus } \\
\text { informant is adapted to the } \\
\text { chronological conflict. So in this study the } \\
\text { informants were Mayor of Samarinda, } \\
\text { member of legislative (DPRD), former } \\
\text { head of the Samarinda Mining and Energy } \\
\text { Office, Mining Advocacy Network } \\
\text { (JATAM), and the community as victims } \\
\text { of the impact of coal mining. To be able to } \\
\text { understand the perceptions of the } \\
\text { informant, the interview was open-ended. } \\
\text { Questions are asked to find out the views } \\
\text { and experiences of the informant. }\end{array}$ \\
\hline 6. & $\begin{array}{l}\text { Qualitatively focuses on processes that } \\
\text { occur as a product or outcome (Creswell, } \\
\text { 2009: 195). }\end{array}$ & $\begin{array}{l}\text { The process observed in this study was the } \\
\text { cause of the conflict then it is based on the } \\
\text { phenomenon of environmental damage } \\
\text { caused by coal mining. So that researchers } \\
\text { are interested to understood how the } \\
\text { process occurs. }\end{array}$ \\
\hline 7. & $\begin{array}{l}\text { The main concern in qualitative research } \\
\text { was data that occurs in certain cases, so did } \\
\text { not need to be generalized (Creswell, 2009: } \\
195) .\end{array}$ & $\begin{array}{l}\text { The object of study in Samarinda City. } \\
\text { and }\end{array}$ \\
\hline
\end{tabular}

Thus, the method was chosen and considered appropriate to examine the causes of vertical conflict between the administration and the community in the case of the impact of coal mining in Samarinda City. Through this approach, it is used to build understanding and provide explanations of the phenomena of the process and explanation of meaning as one of the dominant methods in this study.

\section{RESEARCH RESULT AND DISCUSSION}

The relationship between government and society has a different position, which is different in terms of their functions. The government has the function of carrying out public interests or as a governing subject, while the community is a governed object. Relations between the government and society that are not harmonious often cause a social conflict. As happened in Samarinda City, there was a vertical conflict between the government and the community where the community sued the Samarinda City Administration. This was caused by the city government of Samarinda who was 
Page 232-246. ISBN: 978-602-6 988-75-1

Web Jurnal Online: jurnal.unmuhjember.ac.id

By: Sry Reski Mulka; Budiman; Andi Molang Chaerul; Nur Hasanah

The Impact of Coal Mining in Kota Samarinda

(Case Study of Conflict Between Government With Local Community in 2012-2014)

inconsistent with enforcing regulations regarding the management of coal mines in Samarinda City.

At the end of 2011, the community made a request by blocking the road, carrying out various demonstrations in the office of Mayor of Samarinda. However, protests and objections to the impact of the coal mine voiced by various parties were not enough to get a satisfactory response from the City government. Thus, in early 2012 the community and several non-governmental organizations (NGOs) and student organizations formed a coalition of the Samarinda Suing Movement (GSM). Through the Samarinda Suing Movement (GSM), on June 25, 2013 the people of Samarinda City used the right of citizenship or Citizen Lawsuit (CLS) to sue the Samarinda City Administration institution regarding the policies of the state administration which resulted in problems with the impact of coal mining. Precisely on June 25, 2013 the first trial was held at the Samarinda City court. The trial process was terminated at the 27th session then the demands of Samarinda residents who were members of the Samarinda Gugging Movement (GSM) were partially granted in the court hearing that took place in the Samarinda District Court on July 16 2014. However after the verdict, the Samarinda City Administration appealed the verdict Samarinda City District Court. Thus, based on the chronology of the conflict, the impact of coal mining in Samarinda City is caused by three causal elements; human relations, principle negotiation, and human needs.

\section{Human relations}

Public relations theory explains that conflict occurs because of mistrust and social fragmentation that continue to occur between different or plural groups of people (Simon Fisher, 2001: 7). This is consistent with the public's mistrust of the government regarding the management of coal mining in Samarinda City. Since the existence of regional autonomy was marked by the issuance of Law Number 32 Year 2004 concerning Regional Government, the regions were given the authority to carry out all government functions (except those which were under the authority of the central government). With the implementation of regional autonomy, it has opened space for the government of Samarinda City to take care of its own household, including in the management of coal mining. Under the pretext of an increase towards the welfare of the community, the Government of Samarinda City then began to exploit coal resource wealth by providing permits whose numbers are increasing every year. Based on the results of the study, there are several factors underlying the community's distrust of the Samarinda City Administration, these factors include:

1. Negligence in issuing coal mining business licenses.

The service of granting coal mining management permits carried out by the regional government of Samarinda City has a legal law to give permission to manage coal mines. The institutes for this is the Law of the Republic of Indonesia number 4 of 2009 concerning mining of minerals and coal, which is more specifically in Chapter 7 concerning mining business permits. Seeing from chapter 7 article 37 which states that mining business licenses or mining management permits are given to the Regent / Mayor 
Page 232-246. ISBN: 978-602-6 988-75-1

Web Jurnal Online: jurnal.unmuhjember.ac.id

By: Sry Reski Mulka; Budiman; Andi Molang Chaerul; Nur Hasanah

The Impact of Coal Mining in Kota Samarinda

(Case Study of Conflict Between Government With Local Community in 2012-2014)

if the mining permit area is within the Regency / City. In addition, in providing licensing services, the Government of Samarinda City must pay attention to the 6 principles of public services in accordance with MENPAN's decision No. 63 of 2004 including: (a) Transparency, (b) Accountability, (c) Conditional, (d) Participatory, (e) Similarity Rights and, (f) Balance of Rights and Obligations.

Regarding that, the community considers that the Samarinda City Administration didn't transparent and accountable to the process of issuing coal mining business licenses. The Mayor should consider fulfilling the requirements that must be fulfilled by the applicant. One of the requirements is the ability to manage environmental impacts. However, the business permit granted by the Mayor of Samarinda by issuing a Decree before all requirements are fulfilled, including the absence of environmental documents such as AMDAL and RKL / UPL, guarantees of sincerity and guarantee of reclamation have not been deposited. This shows that in fact many entrepreneurs who hold coal mining licenses in Samarinda City are not eligible to conduct coal mining business so that it has the potential to cause environmental damage. The Mayor of Samarinda should give a coal mining business permit after considering the fulfillment of requirements that must be fulfilled by the applicant. One of the requirements is the ability to manage environmental impacts.

The researcher assessed that coal management in the city showed that there were still weaknesses related to the procedure for granting mining permits. The absence of detailed procedures for the process of granting permits has resulted in a lack of clarity in the mechanism for granting permits for coal mining businesses. This then led to the absence of transparency in the mining sector licensing process and gave confidence to the public that the Government of Samarinda City managed coal resources ineffectively

2. Violation of the Regional Spatial Space (RTRW) of Samarinda City.

Regulation of Samarinda City No. 12 of 2002 concerning the Revision of the Samarinda City Spatial Plan (RTRW), which article 22 states that the area designated as coal mining in Samarinda City is only at Sungai Siring, North Samarinda District. Facts, several mining permits were issued by the Mayor of Samarinda outside the Siring River area. The location of licenses issued by the government of Samarinda City are as follows: 
Proceeding ICOGISS 2019

Page 232-246. ISBN: 978-602-6 988-75-1

Web Jurnal Online: jurnal.unmuhjember.ac.id

By: Sry Reski Mulka; Budiman; Andi Molang Chaerul; Nur Hasanah

The Impact of Coal Mining in Kota Samarinda

(Case Study of Conflict Between Government With Local Community in 2012-2014)

Table 2

List of Coal Mining Business Permits (IUP)

which was issued by the administration of Samarinda City

\begin{tabular}{|c|c|c|c|c|}
\hline No & Company & $\begin{array}{c}\text { Average } \\
\text { Area (Ha) }\end{array}$ & Location & Dsecription \\
\hline 1. & Benua Etam Coal CV & 148,40 & $\begin{array}{l}\text { Kel. Batuas Kec. } \\
\text { Palaran }\end{array}$ & Eksploration \\
\hline 2. & Berkah Ananda CV & 39,78 & $\begin{array}{l}\text { Kel. Bentuas Kec. } \\
\text { Palaran }\end{array}$ & Eksploration \\
\hline 3. & Dua Tiga Empat CV & 203,80 & $\begin{array}{l}\text { Kel. Sempaja Utara } \\
\text { Kec. Samarinda Utara }\end{array}$ & Eksploration \\
\hline 4. & $\begin{array}{l}\text { Koperasi Ponpes Nabil } \\
\text { Husain }\end{array}$ & 197,00 & $\begin{array}{l}\text { Kel. Air Hitam \& } \\
\text { Sempaja Utara Kec. } \\
\text { Samarinda Ulu \& } \\
\text { Samarinda Utara }\end{array}$ & Eksploration \\
\hline 5. & $\begin{array}{l}\text { Fira Pratama Karya } \\
\text { CV }\end{array}$ & 271,70 & $\begin{array}{l}\text { Kel. Sempaja Utara } \\
\text { Kec. Samarinda Utara }\end{array}$ & $\begin{array}{l}\text { Production } \\
\text { Operation }\end{array}$ \\
\hline 6. & $\begin{array}{l}\text { Anugrah Bara Insan } \\
\mathrm{CV}\end{array}$ & 198,30 & $\begin{array}{l}\text { Kel. Bentuas, Kec. } \\
\text { Palaran }\end{array}$ & $\begin{array}{l}\text { Production } \\
\text { Operation }\end{array}$ \\
\hline 7. & $\begin{array}{l}\text { Anugrah Berlian } \\
\text { Pratama Coal CV }\end{array}$ & 75,08 & $\begin{array}{l}\text { Kel. Bentuas, Kec. } \\
\text { Palaran }\end{array}$ & $\begin{array}{l}\text { Production } \\
\text { Operation }\end{array}$ \\
\hline 8. & Arjuna CV & $1.452,00$ & $\begin{array}{l}\text { Kel. Sambutan, } \\
\text { Makroman \& Pulau } \\
\text { Atas Kec. Samarinda } \\
\text { Ilir (Sambutan) }\end{array}$ & $\begin{array}{l}\text { Production } \\
\text { Operation }\end{array}$ \\
\hline 9. & Atap Tri Utama CV & 414,40 & $\begin{array}{l}\text { Kel. Bentuas, Kec. } \\
\text { Palaran }\end{array}$ & $\begin{array}{l}\text { Production } \\
\text { Operation }\end{array}$ \\
\hline 10. & $\begin{array}{l}\text { Bara Energi Kaltim } \\
\text { CV }\end{array}$ & 196,70 & $\begin{array}{l}\text { Kel. Simpang Pasir } \\
\text { Kec. Palaran }\end{array}$ & $\begin{array}{l}\text { Production } \\
\text { Operation }\end{array}$ \\
\hline 11. & $\begin{array}{l}\text { Bara Pratama Abadi } \\
\text { CV }\end{array}$ & 199,80 & $\begin{array}{l}\text { Kel. Mugirejo Kec. } \\
\text { Samarinda Utara }\end{array}$ & $\begin{array}{c}\text { Production } \\
\text { Operation }\end{array}$ \\
\hline 12. & $\begin{array}{l}\text { Bara Sumber Makmur } \\
\text { KOPTAM }\end{array}$ & 87,51 & $\begin{array}{l}\text { Kel. Lok Bahu Kec. } \\
\text { Sungai Kunjang }\end{array}$ & $\begin{array}{l}\text { Production } \\
\text { Operation }\end{array}$ \\
\hline 13. & Baratama Makmur CV & 120,10 & $\begin{array}{l}\text { Kel. Sempaja Kec. } \\
\text { Samarinda Utara }\end{array}$ & $\begin{array}{l}\text { Production } \\
\text { Operation }\end{array}$ \\
\hline 14. & Baratama Makmur CV & 84,33 & $\begin{array}{l}\text { Kel. Air Putih \& } \\
\text { Sempaja Kec. } \\
\text { Samarinda Ulu \& } \\
\text { Samarinda Utara }\end{array}$ & $\begin{array}{l}\text { Production } \\
\text { Operation }\end{array}$ \\
\hline 15. & Benua Etam Coal PT & 312,40 & $\begin{array}{l}\text { Kel. Bentuas Kec. } \\
\text { Palaran }\end{array}$ & $\begin{array}{l}\text { Production } \\
\text { Operation }\end{array}$ \\
\hline 16. & Berkah Nanda CV & 435,50 & $\begin{array}{l}\text { Kel Bukuan \& Bentuas } \\
\text { Kec. Palaran }\end{array}$ & $\begin{array}{l}\text { Production } \\
\text { Operation }\end{array}$ \\
\hline 17. & $\begin{array}{l}\text { Bismillahi Res Kaltim } \\
\text { CV }\end{array}$ & 100,30 & $\begin{array}{l}\text { Kel. Lempake \& } \\
\text { Tanah Merah Kec. } \\
\text { Samarinda Utara }\end{array}$ & $\begin{array}{l}\text { Production } \\
\text { Operation }\end{array}$ \\
\hline 18. & Benua Rizky Armia & 948,20 & Kel. Bentuas Kec. & Production \\
\hline
\end{tabular}


Proceeding ICOGISS 2019

Page 232-246. ISBN: 978-602-6 988-75-1

Web Jurnal Online: jurnal.unmuhjember.ac.id

By: Sry Reski Mulka; Budiman; Andi Molang Chaerul; Nur Hasanah

The Impact of Coal Mining in Kota Samarinda

(Case Study of Conflict Between Government With Local Community in 2012-2014)

\begin{tabular}{|c|c|c|c|c|}
\hline & $\mathrm{PT}$ & & Palaran & Operation \\
\hline 19. & $\begin{array}{l}\text { Benua Rizky Amalia } \\
\text { PT }\end{array}$ & 199,90 & $\begin{array}{l}\text { Kel. Sungai Siring } \\
\text { Kec. Samarinda Utara }\end{array}$ & $\begin{array}{c}\text { Production } \\
\text { Operation }\end{array}$ \\
\hline 20. & $\begin{array}{l}\text { Bukit Pinang Bahari } \\
\text { CV }\end{array}$ & 63,80 & $\begin{array}{l}\text { Kel Air Hitam Kec. } \\
\text { Samarinda Ulu }\end{array}$ & $\begin{array}{c}\text { Production } \\
\text { Operation }\end{array}$ \\
\hline 21. & $\begin{array}{l}\text { Bukuan Jaya Abadi } \\
\text { CV }\end{array}$ & 196,20 & $\begin{array}{l}\text { Kel. Bentuas Kec. } \\
\text { Palaran }\end{array}$ & $\begin{array}{c}\text { Production } \\
\text { Operation }\end{array}$ \\
\hline 22. & Busur Abadi CV & 791,76 & $\begin{array}{l}\text { Kel Air Putih,Air } \\
\text { Hitam,Bukit Pinang \& } \\
\text { Sempaja Utara Kec. } \\
\text { Samarinda Ulu \& } \\
\text { Utara }\end{array}$ & $\begin{array}{c}\text { Production } \\
\text { Operation }\end{array}$ \\
\hline 23. & $\begin{array}{l}\text { Brilian Alam Sejahtera } \\
\text { CV }\end{array}$ & 198,00 & $\begin{array}{l}\text { Kel. Bentuas Kec. } \\
\text { Palaran }\end{array}$ & $\begin{array}{c}\text { Production } \\
\text { Operation }\end{array}$ \\
\hline 24. & $\begin{array}{l}\text { Cahaya Energi Mandiri } \\
\text { PT }\end{array}$ & $1.680,35$ & $\begin{array}{l}\text { Kel. Sungai } \\
\text { Siring,Sungai Pinang } \\
\text { Dalam,Sambutan,Tana } \\
\text { h Merah, Kec. } \\
\text { Samarinda Ilir \& Utara }\end{array}$ & $\begin{array}{l}\text { Production } \\
\text { Operation }\end{array}$ \\
\hline 25 . & Dunia Usaha Maju PT & $1.351,00$ & $\begin{array}{l}\text { Kel. Sungai Siring } \\
\text { Lempake \& Sempaja } \\
\text { Kec. Samarinda Utara }\end{array}$ & $\begin{array}{c}\text { Production } \\
\text { Operation }\end{array}$ \\
\hline 26. & $\begin{array}{l}\text { Energi Cahaya } \\
\text { Industritama PT }\end{array}$ & $1.977,33$ & $\begin{array}{l}\text { Kel. Rawa Makmur, } \\
\text { Handil Bakti, Bukuan } \\
\text { \& Bentuas Kec. } \\
\text { Palaran }\end{array}$ & $\begin{array}{l}\text { Production } \\
\text { Operation }\end{array}$ \\
\hline 27. & $\begin{array}{l}\text { Gelinggang Mandiri } \\
\text { KSU }\end{array}$ & 101,60 & $\begin{array}{l}\text { Kel. Handil Bhakti \& } \\
\text { Bentuas Kec. Palaran }\end{array}$ & $\begin{array}{c}\text { Production } \\
\text { Operation }\end{array}$ \\
\hline 28. & Graha Benua Etam PT & 493,70 & $\begin{array}{l}\text { Kel. Sempaja Utara } \\
\text { Kec. Samarinda Utara }\end{array}$ & $\begin{array}{c}\text { Production } \\
\text { Operation }\end{array}$ \\
\hline 29. & Himko Coal PT & 125,90 & $\begin{array}{l}\text { Kel. Sambutan Kec. } \\
\text { Samarinda Ilir }\end{array}$ & $\begin{array}{c}\text { Production } \\
\text { Operation } \\
\end{array}$ \\
\hline 30. & Indokal Prima Jaya PT & 79,13 & $\begin{array}{l}\text { Kel. Sungai Siring } \\
\text { Kec. Samarinda Utara }\end{array}$ & $\begin{array}{c}\text { Production } \\
\text { Operation }\end{array}$ \\
\hline 31. & $\begin{array}{l}\text { Infraergia Benua } \\
\text { Utama CV }\end{array}$ & 106,30 & $\begin{array}{l}\text { Kel Loa Buah \& Loa } \\
\text { Bakung Kec. Sungai } \\
\text { Kunjang }\end{array}$ & $\begin{array}{c}\text { Production } \\
\text { Operation }\end{array}$ \\
\hline 32. & $\begin{array}{l}\text { Internasional Prima } \\
\text { Coal PT }\end{array}$ & $3.238,00$ & $\begin{array}{l}\text { Kel. Handil Bhakti \& } \\
\text { Bentuas Kec. Palaran }\end{array}$ & $\begin{array}{c}\text { Production } \\
\text { Operation }\end{array}$ \\
\hline 33. & $\begin{array}{l}\text { Kalimantan Sumber } \\
\text { Energi CV }\end{array}$ & 75,07 & $\begin{array}{l}\text { Kel. Sambutan Kec. } \\
\text { Samarinda Ilir }\end{array}$ & $\begin{array}{c}\text { Operasi } \\
\text { Produksi }\end{array}$ \\
\hline 34. & Kopta KUD & 97,35 & $\begin{array}{l}\text { Kel. Air Hitam \& } \\
\text { Sempaja Utara Kec } \\
\text { Samarinda Ulu \& } \\
\text { Samarinda Utara }\end{array}$ & $\begin{array}{c}\text { Production } \\
\text { Operation }\end{array}$ \\
\hline 35. & $\begin{array}{l}\text { Krida Makmur } \\
\text { Bersama PT }\end{array}$ & 545,00 & $\begin{array}{l}\text { Kel. Bentuas Kec. } \\
\text { Palaran }\end{array}$ & $\begin{array}{c}\text { Production } \\
\text { Operation }\end{array}$ \\
\hline 36. & Limbuh CV & $1.209,20$ & $\begin{array}{l}\text { Kel. Sungai Pinang } \\
\text { Dalam \& Sambutan }\end{array}$ & $\begin{array}{c}\text { Production } \\
\text { Operation }\end{array}$ \\
\hline
\end{tabular}


Proceeding ICOGISS 2019

Page 232-246. ISBN: 978-602-6 988-75-1

Web Jurnal Online: jurnal.unmuhjember.ac.id

By: Sry Reski Mulka; Budiman; Andi Molang Chaerul; Nur Hasanah

The Impact of Coal Mining in Kota Samarinda

(Case Study of Conflict Between Government With Local Community in 2012-2014)

\begin{tabular}{|c|c|c|c|c|}
\hline & & & $\begin{array}{l}\text { Kec. Samarinda Utara } \\
\text { \& Samarinda Ilir }\end{array}$ & \\
\hline 37. & Mada Perkasa CV & 496,20 & $\begin{array}{l}\text { Kel Bukit Pinang \& } \\
\text { Sempaja Utara Kec. } \\
\text { Samarinda Ulu \& } \\
\text { Samarinda Utara }\end{array}$ & $\begin{array}{c}\text { Production } \\
\text { Operation }\end{array}$ \\
\hline 38. & $\begin{array}{l}\text { Mahakam Bara Utama } \\
\text { PT }\end{array}$ & 194,00 & $\begin{array}{l}\text { Kel Bukit Pinang \& } \\
\text { Sempaja Utara Kec. } \\
\text { Samarinda Ulu \& } \\
\text { Samarinda Utara }\end{array}$ & $\begin{array}{l}\text { Production } \\
\text { Operation }\end{array}$ \\
\hline 39. & Mahatidana KSU & 193,20 & $\begin{array}{l}\text { Kel. Lempake \& } \\
\text { Gunung Lingai Kec. } \\
\text { Samarinda Utara }\end{array}$ & $\begin{array}{c}\text { Production } \\
\text { Operation }\end{array}$ \\
\hline 40. & Makrri Tutu Abadi CV & 139,70 & $\begin{array}{l}\text { Kel. Handil Bhakti \& } \\
\text { Rawa Makmur Kec. } \\
\text { Palaran }\end{array}$ & $\begin{array}{c}\text { Production } \\
\text { Operation }\end{array}$ \\
\hline 41. & Mampala Jaya CV & 595,10 & $\begin{array}{l}\text { Kel Bentuas Kec. } \\
\text { Palaran }\end{array}$ & $\begin{array}{c}\text { Production } \\
\text { Operation }\end{array}$ \\
\hline 42. & Mampala Jaya CV & 185,60 & $\begin{array}{l}\text { Kel. Bukuan \&. } \\
\text { Bentuas, Kec. Palaran }\end{array}$ & $\begin{array}{c}\text { Production } \\
\text { Operation }\end{array}$ \\
\hline 43. & Mutiara Etam Coal CV & 546,20 & $\begin{array}{l}\text { Kel. Bentuas, Kec. } \\
\text { Palaran }\end{array}$ & $\begin{array}{c}\text { Production } \\
\text { Operation }\end{array}$ \\
\hline 44. & $\begin{array}{l}\text { Nuanscipta Coal } \\
\text { Invesment PT }\end{array}$ & $2.003,00$ & $\begin{array}{l}\text { Kel. Handil Bhakti \& } \\
\text { Bentuas, Kec. Palaran }\end{array}$ & $\begin{array}{c}\text { Production } \\
\text { Operation }\end{array}$ \\
\hline 45. & $\begin{array}{l}\text { Panca Bara Sejahtera } \\
\text { CV }\end{array}$ & 133,00 & $\begin{array}{l}\text { Kel Air Hitam \& } \\
\text { Sempaja Kec. } \\
\text { Samarinda Ulu \& } \\
\text { Samarinda Utara }\end{array}$ & $\begin{array}{c}\text { Production } \\
\text { Operation }\end{array}$ \\
\hline 46. & $\begin{array}{l}\text { Panca Prima Mining } \\
\text { PT }\end{array}$ & 950,20 & $\begin{array}{l}\text { Kel. Sambutan \&Pulau } \\
\text { Atas Kec. Samarinda } \\
\text { Ilir }\end{array}$ & $\begin{array}{c}\text { Production } \\
\text { Operation }\end{array}$ \\
\hline 47. & $\begin{array}{l}\text { Piawai Bumi Alam } \\
\text { Perkasa CV }\end{array}$ & 83,66 & $\begin{array}{l}\text { Kel Sempaja Selatan } \\
\text { Kec. Samarinda Utara }\end{array}$ & $\begin{array}{c}\text { Production } \\
\text { Operation }\end{array}$ \\
\hline 48. & Puang Cakrabuana CV & 42,93 & $\begin{array}{l}\text { Kel. Simpang Pasir } \\
\text { Palaran }\end{array}$ & $\begin{array}{c}\text { Production } \\
\text { Operation }\end{array}$ \\
\hline 49. & Putra Mandiri KSU & 99,60 & $\begin{array}{l}\text { Kel. Lempake Kec. } \\
\text { Samarinda Utara }\end{array}$ & $\begin{array}{c}\text { Production } \\
\text { Operation }\end{array}$ \\
\hline 50. & $\begin{array}{l}\text { Rinda Kaltim Anugrah } \\
\text { CV }\end{array}$ & 137,40 & $\begin{array}{l}\text { Kel. Lok Bahu \& Loa } \\
\text { Bakung Kec. Sungai } \\
\text { Kunjang }\end{array}$ & $\begin{array}{c}\text { Production } \\
\text { Operation }\end{array}$ \\
\hline 51. & $\begin{array}{l}\text { Rinda Kaltim Anugrah } \\
\text { CV }\end{array}$ & 196,40 & $\begin{array}{l}\text { Kel. Lempake \& } \\
\text { Tanah Merah Kec. } \\
\text { Samarinda Utara }\end{array}$ & $\begin{array}{c}\text { Production } \\
\text { Operation }\end{array}$ \\
\hline 52. & $\begin{array}{l}\text { Rinda Putra Sejahtera } \\
\text { CV }\end{array}$ & 596,30 & $\begin{array}{l}\text { Kel. Suangai Siring } \\
\text { Kec. Samarinda Utara }\end{array}$ & $\begin{array}{c}\text { Production } \\
\text { Operation }\end{array}$ \\
\hline 53. & Sakha CV & 94,92 & $\begin{array}{l}\text { Kel. Tanah Merah } \\
\text { Kec. Samarinda Utara }\end{array}$ & $\begin{array}{c}\text { Production } \\
\text { Operation }\end{array}$ \\
\hline 54. & $\begin{array}{l}\text { Sungai Berlian Jaya } \\
\text { CV }\end{array}$ & 170,80 & $\begin{array}{l}\text { Kel. Bentuas, Kec. } \\
\text { Palaran }\end{array}$ & $\begin{array}{c}\text { Production } \\
\text { Operation }\end{array}$ \\
\hline
\end{tabular}


Proceeding ICOGISS 2019

Page 232-246. ISBN: 978-602-6 988-75-1

Web Jurnal Online: jurnal.unmuhjember.ac.id

By: Sry Reski Mulka; Budiman; Andi Molang Chaerul; Nur Hasanah

The Impact of Coal Mining in Kota Samarinda

(Case Study of Conflict Between Government With Local Community in 2012-2014)

\begin{tabular}{|c|l|c|l|c|}
\hline 55. & $\begin{array}{l}\text { Tempaure Jaya } \\
\text { Mandiri Coal CV }\end{array}$ & 54,10 & $\begin{array}{l}\text { Kel. Loa Buah Kec. } \\
\text { Sungai Kunjang }\end{array}$ & $\begin{array}{c}\text { Production } \\
\text { Operation }\end{array}$ \\
\hline 56. & Tiara Bara Borneo PT & 564,80 & $\begin{array}{l}\text { Kel. Tanah Merah } \\
\text { Kec. Samarinda Utara }\end{array}$ & $\begin{array}{c}\text { Production } \\
\text { Operation }\end{array}$ \\
\hline 57. & $\begin{array}{l}\text { Transisi Energi } \\
\text { Satunama PT }\end{array}$ & 946,60 & $\begin{array}{l}\text { Kel. Loa Buah Kec. } \\
\text { Sungai Kunjang }\end{array}$ & $\begin{array}{l}\text { Production } \\
\text { Operation }\end{array}$ \\
\hline 58. & $\begin{array}{l}\text { Transisi Energi } \\
\text { Satunama PT }\end{array}$ & 195,60 & $\begin{array}{l}\text { Kel. Lok Bahu Kec. } \\
\text { Sungai Kunjang }\end{array}$ & $\begin{array}{l}\text { Production } \\
\text { Operation }\end{array}$ \\
\hline 59. & Tujuh Tujuh CV & 189,40 & $\begin{array}{l}\text { Kel. Tanah Merah } \\
\text { Kec. Samarinda Utara }\end{array}$ & $\begin{array}{l}\text { Production } \\
\text { Operation }\end{array}$ \\
\hline 60. & $\begin{array}{l}\text { Tunggal Firdaus } \\
\text { Kaltim CV }\end{array}$ & 67,75 & $\begin{array}{l}\text { Kel. Bentuas, Kec. } \\
\text { Palaran }\end{array}$ & $\begin{array}{l}\text { Production } \\
\text { Operation }\end{array}$ \\
\hline 61. & Utia Iimdaya CV & 199,60 & $\begin{array}{l}\text { Kel. Bukit Pinang Kec. } \\
\text { Samarinda Ulu }\end{array}$ & $\begin{array}{c}\text { Production } \\
\text { Operation }\end{array}$ \\
\hline 62. & Prima Coal Mining CV & 155,58 & $\begin{array}{l}\text { Kel. Sempaja Utara } \\
\text { Kec. Samarinda Utara }\end{array}$ & IUP Revoked \\
\hline 63. & Bumi Betua PT & 164,60 & $\begin{array}{l}\text { Kel. Loa Buah Kec. } \\
\text { Sungai Kunjang }\end{array}$ & IUP Revoked \\
\hline & TOTAL & $\mathbf{2 6 . 0 8 9 , 9 9}$ & & \\
\hline
\end{tabular}

Source: Energy and Mining Service Of Kota Samarinda.

According to an Article 11 paragraph 1 of Law No. 26 of 2007 cocerning Spatial Planning, Regional Government was represented by the Mayor has full authority for it. But the facts, that he violated the rules by issued coal mining licenses that were not in similar with spatial planning of the Samarinda City Spatial Plan.

\section{Principle Negotiation}

Principle negotiation theory assumes that the cause of a conflict was due to inconsistent positions and differences of views by parties experienced conflict (Simon Fisher, 2001: 8). Differences are things that always exist in the social life, both differences between individuals or groups with others. According to Soerjono Soekanto (2006: 91-92), when at the same time each individual or group carried out the same activities and had views with different goals, this would brought social conflict in the community. So, it could be said that the needs or interests of people towards the same object sometimes vary, for example incompatibility of views between the community and the government in Samarinda City regarding land use. The Government of Samarinda City wants the potential of Natural Resources (SDA to be managed and utilized properly, that is by involved coal mining companies`as seekers and managers of the potential that exists on the field. The results would then provide welfare to the surrounding.

On the other hand, the community considers that the potential of the land was very suitable for agricultural land and should not be damaged or exploited, because it greatly affects the survival of the people who in fact are farmers. If the land becomes damaged, it will cause various impacts on the lives of surrounding, such as lack of clean water and environment pollution. The community also felt that the management of the land into mining land was not solely dominated by the desire to increase welfare, because when 
Page 232-246. ISBN: 978-602-6 988-75-1

Web Jurnal Online: jurnal.unmuhjember.ac.id

By: Sry Reski Mulka; Budiman; Andi Molang Chaerul; Nur Hasanah

The Impact of Coal Mining in Kota Samarinda

(Case Study of Conflict Between Government With Local Community in 2012-2014)

viewed amount of contribution of the coal mining sector to the economy of Samarinda City which turned out to be relatively small, it was only 6.3 percent of total domestic income regional gross (PDRB), but the largest sector was the trade, hotel and tourism sector by 28 percent, the processing industry by 20 percent and services by 12 percent.

\section{Human Needs}

The theory assumes that conflicts that arise in the community are caused by basic human needs, such as physical, mental and social needs that are not fulfilled or obstructed (Simon Fisher, 2001: 8). By the negative impact caused by coal mining, some community needs were blocked or not fulfilled. People need a good environ. But the damage caused by coal mining has reduced the environmental feasibility of the people. Such erratic weather changes, the air becomes more warm, rain comes suddenly and there was an increased flooding quantity since 2008 until now and the occurrence of droughts in a number of areas. The last, the people are susceptible to Acute Respiratory Tract Infections (ISPA), which is caused by environmental pollution due to coal mining.

Moreover, the people who live around the coal mining mostly are farmers. The mining have provided unfit lives for the community such as the increasingly loss of clean water sources, the land for absorb water, mud floods in mining areas so that they can clog ditches (sewers) which then cause flooding in settlements and rice fields of community, dust that polluted the air, and also the existence of large losses due to the breakdown of embankment ponds for fish farming. The Samarinda City Administration has tried to supervise the company by directly pressing the troubled companies and the government always provides guidance to the company. However, it has not been effective yet, as more companies are not committed to the environment so that the pollution more increasing.

\section{CONCLUSION}

Based on the results, we draws the conclusion that the conflict between the administration and the community of the city due to the impact of coal mining in 20122014 was caused by three causes, namely:

1. Public relations

The public's distrust, includes, first;: the administration neglected in issuing coal mining business licenses, second, violations of the RTRW and they never socialization before or after the issuance of coal mining business licenses was conducted.

2. Negotiation of principles

There are different views between the administration and the community for land management. Where the land that is given the permits for coal mining is just suitable for agricultural, while they used it for a coal mining by the reasons to improve community welfare.

3. Human needs

By all the impacts, some community needs are not fulfilled, such as a good and healthy environment. Many people suffer from Acute Respiratory Tract 
Page 232-246. ISBN: 978-602-6 988-75-1

Web Jurnal Online: jurnal.unmuhjember.ac.id By: Sry Reski Mulka; Budiman; Andi Molang Chaerul; Nur Hasanah The Impact of Coal Mining in Kota Samarinda

(Case Study of Conflict Between Government With Local Community in 2012-2014)

Infection (ARI) or ISPA, then damaged road infrastructure, as well as agricultural land and fish cultivation that are polluted.

\section{SUGGESTION}

1. Because the negligent of administration in issuing mining licenses and violation of the RTRW, it should immediately conduct an evaluation of all regulation permits that have been issued and it must be carried out transparently to them who affected.

2. Because the location was an agricultural and residential area, they should make strategic efforts in protecting it and pollution as a result of mining activities.

3. Regarding the existence of several community needs that are not fulfilled due to the impact, they should make appropriate compensation to the affected communities.

4. Due to the absence of conflict resolution, it is expected that they have to carried out various intensive ways to approach mining affected communities. 
Page 232-246. ISBN: 978-602-6 988-75-1

Web Jurnal Online: jurnal.unmuhjember.ac.id

By: Sry Reski Mulka; Budiman; Andi Molang Chaerul; Nur Hasanah

The Impact of Coal Mining in Kota Samarinda

(Case Study of Conflict Between Government With Local Community in 2012-2014)

\section{REFERENCE}

Abdi, Furkan. 2009. Konflik antarwarga (Studi kasus Desa Renda dan Desa Ngali Kec. Belo Kab. Bima NTB). Makassar: FISIP Universitas Hasanuddin.

Arikunto, Suharsimi. 2005. Manajemen Penelitian. Jakarta: Rineka Cipta.

Ari, S., \& Norrbacka, R. I. 2009. Trust and Integrity Violations in Finnish

Public. Halduskultuur, 10:74-93.

Bungin, Burhan. 2007. Penelitian Kualitatif. Jakarta: Kencana Prenada Media Group.

Creswell, John W. 2010. Research Design Pendekatan Kualitatif, Kuantitatif, dan Mixed. Yogyakarta: Pustaka Pelajar.

Cresswell. Jhon W. 20013. Research Design. Yogyakarta: Pustaka Pelajar.

Diana Francis. 2006. Teori Dasar Transformasi Konflik Sosial, Yogyakarta: Quills

Fard, H. D., \& Rostamy, A. A. 2007. Promoting Public Trust in Public Organization: Explaining the Role of Public Accountability. Public Organiz Rev, 7:331-344.

Idrus, Muhammad. 2009. Metode Penelitian Ilmu Sosial. Yogyakarta: Erlangga.

Kansil, C.S.T. 1984. Desa Kita Dalam Peraturan Tata Pemerintahan Daerah dan Desa. Jakarta: Ghalia Indonesia.

Labolo, Muhadam. 2013. Memahami Ilmu Pemerintahan. Jakarta: Rajawali Pers.

Moleong. 2010. Metodologi Penelitian Kualitatif. Bandung: PT. Remaja Rosdakarya 